\title{
RNAi strategies to silence HIV-1
}

\author{
Julia Eekels ${ }^{1 *}$, Veronica lannuci ${ }^{2}$, Rienk E Jeeninga ${ }^{1}$, Bruno Verhasselt ${ }^{2}$, Ben Berkhout ${ }^{1}$ \\ From Frontiers of Retrovirology 2011 \\ Amsterdam, The Netherlands. 3-5 October 2011
}

RNAi is a sequence-specific gene silencing mechanism induced by double-stranded RNA and a promising tool for the development of a durable gene therapy against HIV-1. Such RNAi attack usually focuses on targets within the HIV-1 RNA genome. Despite potent inhibition, we previously observed the rapid selection of RNAi-resistant HIV-1 variants with a mutated target sequence. A number of strategies were tested to prevent viral escape. Similar to the success of combination therapy with multiple anti-retroviral drugs, one can target HIV-1 with multiple short hairpin RNAs (shRNAs). Alternatively, one can design second-generation shRNAs to target favorite RNAi-resistance mutations in order to block specific viral escape routes. One could also combine RNAi with regular antiviral drug regimens. Another strategy involves the use of RNAi against cellular proteins that are involved in HIV-1 replication. The idea is that viral escape is more difficult in this setting. Many cellular co-factors have been described in literature, e.g. based on large RNAi-screens in cell lines. We have shown that long-term inhibition of HIV-1 replication is possible with RNAi against cellular co-factors. To identify relevant co-factors that are not essential for cellular function, primary cells are to be preferred over $\mathrm{T}$ cell lines. We propose that RNAi against both viral and cellular targets could be used as a new therapeutic approach in the combat against HIV-1 infection.

\footnotetext{
Author details

'Laboratory of Experimental Virology, University of Amsterdam, Meibergdreef 15, 1105 AZ Amsterdam, The Netherlands. ${ }^{2}$ Department of Clinical Chemistry, Microbiology and Immunology, Ghent University, De Pintelaan 185, 9000 Gent, Belgium.
}

Published: 3 October 2011

'Laboratory of Experimental Virology, University of Amsterdam, Meibergdreef 15, 1105 AZ Amsterdam, The Netherlands

Full list of author information is available at the end of the article
doi:10.1186/1742-4690-8-S2-034

Cite this article as: Eekels et al:: RNAi strategies to silence HIV-1.

Retrovirology 2011 8(Suppl 2):034.
Submit your next manuscript to BioMed Central and take full advantage of:

- Convenient online submission

- Thorough peer review

- No space constraints or color figure charges

- Immediate publication on acceptance

- Inclusion in PubMed, CAS, Scopus and Google Scholar

- Research which is freely available for redistribution

Submit your manuscript at www.biomedcentral.com/submit

\section{() Biomed Central}

